\title{
Systems Analysis of Coupled Natural and Human Processes in the Mekong River Basin
}

\author{
Venkataramana Sridhar ${ }^{1, *(\mathbb{D})}$, Syed Azhar Ali ${ }^{1}\left[\right.$ and David J. Sample ${ }^{2} \mathbb{( D )}$ \\ 1 Biological Systems Engineering, Virginia Tech, Blacksburg, VA 24061, USA; syedaa@vt.edu \\ 2 Hampton Roads Agricultural Research and Extension Center, Virginia Tech, Virginia Beach, VA 23455, USA; \\ dsample@vt.edu \\ * Correspondence: vsri@vt.edu
}

Citation: Sridhar, V.; Ali, S.A.; Sample, D.J. Systems Analysis of Coupled Natural and Human Processes in the Mekong River Basin. Hydrology 2021, 8, 140. https:// doi.org/10.3390/hydrology 8030140

Academic Editor: Ezio Todini

Received: 11 July 2021

Accepted: 8 September 2021

Published: 12 September 2021

Publisher's Note: MDPI stays neutral with regard to jurisdictional claims in published maps and institutional affiliations.

Copyright: () 2021 by the authors. Licensee MDPI, Basel, Switzerland. This article is an open access article distributed under the terms and conditions of the Creative Commons Attribution (CC BY) license (https:// creativecommons.org/licenses/by/ $4.0 /)$.

\begin{abstract}
The Mekong River Basin is one of the world's major transboundary basins. The hydrology, agriculture, ecology, and other watershed functions are constantly changing as a result of a variety of human activities carried out inside and by neighboring countries including China, Myanmar, Thailand, Laos, Cambodia, and Vietnam in order to meet increased food and water demands for an increasing population. The Mekong River, which provides irrigation and fishing for a population of over 60 million people, also has an estimated 88,000 MW of untapped hydropower potential. The construction of dams for energy supply has a wide-ranging impact on downstream reservoir regions, resulting in unprecedented changes in hydrologic functions, the environment, and people's livelihoods. We present a holistic view of how external stressors such as climate change and variability, land cover, and land-use change affect supply and demand. We present an integrated modeling framework for analyzing the supply-demand scenarios and tradeoffs between different sectors. Specifically, we evaluated the impacts of future climate on irrigation, hydropower, and other needs in the basin through a feedback loop. We focused on hydrologic extremes to evaluate their impacts on the reservoir operations during flood and low flow events. The inflow is projected to change by $+13 \%$ to $-50 \%$ in the future, while a $0.25 \%\left(15.24\right.$ billion $\left.\mathrm{m}^{3}\right)$ reduction is projected for the net irrigation water requirement (NIWR). A unit percentage increase in irrigation demand will reduce energy generation by $0.15 \%$, but climate change has a beneficial impact on dam performance with a predicted increase in energy generation and supply to all sectors. Flood events will cause excessive stress on reservoir operation to handle up to six times more flow volumes; however, the low-flow events will marginally affect the system. While the flow and storage rule curves consider both supply and demand, changing human water use comes second to changing climate or other biophysical considerations. This paper emphasizes the importance of considering feedback between climatewater-human society in the systems modeling framework in order to meet societal and ecological challenges. The findings will provide information on the risks and tradeoffs that exist in the water, energy, and food sectors of the basin.
\end{abstract}

Keywords: hydrology; systems modeling; anthropogenic impacts; Mekong River Basin

\section{Introduction}

The Mekong River begins at an elevation of approximately $5200 \mathrm{~m}$ on the Tibetan Plateau and runs $4800 \mathrm{~km}$ southeast to the South China Sea. It is home to 60 million people, passing through China, Myanmar, Laos, Thailand, Cambodia, and Vietnam. The Mekong is the world's tenth-largest river by discharge, with 475 billion cubic meters of runoff at the delta's mouth. It has a drainage area of 795,000 square kilometers. This river basin has two distinct flow seasons: the rainy season, which runs from May to October, and the dry season, which runs from November to April. Several dams have been or are being erected in the Mekong's tributaries and main stem, and the Mekong, formerly considered one of the world's last great unregulated rivers, has been considerably altered by massive amounts of 
irrigation water diverted from the delta region. As a result, the river altered in nature, and the World Wildlife Fund (WWF) named it one of the top 10 most endangered rivers on the planet [1]. The Mekong has therefore become an ideal testbed to evaluate the feedbacks in the socio-hydrological framework. As with many river basins undergoing changes in physiography, landcover, and natural and human-induced climate change, any assessment of the water cycle in this basin becomes extremely valuable when it aims to integrate human-water systems as a use-inspired scientific pursuit to understand, characterize, and quantify flows and stocks across time and space scales. Hydrology is impacted because of human-induced changes, but in modeling hydrologic conditions including droughts [2-4], reservoir operations [5,6], water management and tradeoff analysis in the context of hydropower generation [7-9], ecological flow requirements [10,11], and transboundary water governance $[12,13]$ are also constantly assessed. The pace of change requires the integration of new methods, data, and modeling techniques to understand the flows, supply, and demand requirements with a focus on multi-sectoral water needs in a feedback framework. Changes in the Salmon and Snake rivers' flow magnitudes [14,15], evapotranspiration changes [16-18], and soil moisture and drought in the Chesapeake Bay watershed $[19,20]$ suggest that an integrated model that covers the systems and physically based modeling aspects will be ideal for the Mekong River Basin (MRB). Since the system is not natural or pristine due to human-induced changes, the inclusion of those changes in the system dynamics framework provides an ideal environment to analyze the water management and reservoir operation in fulfilling the water demands of diverse sectors under the influence of dynamic inflows, water demands, and climate impacts. The system dynamics framework provides the advantage of making intercomparison between the system behavior, due to variation of any single parameter while the others remain constant, through the generation of different scenarios. Nexus approaches are recognized as an effective way to provide a sustainable solution to natural resources scarcity, accomplished with the challenge of climate change and anthropogenic activities [21-23].

The dynamic system approach is used in the MRB to evaluate sustainable adaptation strategies for vulnerable mega deltas rice agriculture in Vietnam, the water supply-power generation-environment (WPE) nexus for China's Hehuang region, and to estimate the effects of changing variables on the hydropower-food supply nexus [24-27]. However, several previous studies in the MRB are limited to the region and have not been fully explored with an integrated approach to study all of these constantly changing sectors concurrently.

The objective of this article is to provide the general framework for integrated modeling of food-energy-water systems in a human-natural system impacted by climate change and hydropower development projects that can aid in the sustainable development and management of the basin. Specifically, this study aimed to investigate the effects of expected climate change on streamflow and irrigation requirements, assess system stress in the face of extreme events in a changing climate, investigate the tradeoff between the energy and irrigation sectors under various scenarios of agricultural expansion-intensification in the system dynamics environment and finally determine the future water needs of irrigation, energy, municipal, and industrial sectors based on projected population and GCM datasets in order to predict future situations.

\section{Background}

The MRB has a narrow headwater catchment that gradually widens downstream, with the basin's widest part towards the delta region. The basin is shown in Figure 1 with flow stations and major dams. The Mekong river's hydrology is characterized by a large mean annual discharge, which occurs primarily during the monsoon season. In most years, the annual minimum daily discharge occurs in early April. In late May, flows soon double, and the flood season begins in late June. In November, when the dry season begins, the river reaches its baseflow. Precipitation is distributed in a heterogeneous pattern from east to west, with a mean annual value of $1200 \mathrm{~mm}$. Temperature and elevation variations, on the other hand, follow a north-to-south gradient. The monthly mean temperature ranges 
from $38^{\circ} \mathrm{C}$ in March and April to $15^{\circ} \mathrm{C}$ in November and February. The floodplain of the Mekong River is relatively limited just before reaching Cambodia because the river drops by more than $4900 \mathrm{~m}$ from its source and follows a narrow path. However, in Cambodia, the area of inundation is several hundred square kilometers, including the Tonle Sap lake basin, and the flooding potential is much lower in the delta until the confluence with the South China Sea. Croplands cover the majority of the basin $(40 \%)$, followed by evergreen broadleaf forest $(28 \%)$, closed shrublands $(10.3 \%)$, and grasslands $(9.3 \%)$. Extraction of river flow for irrigation amounts to the largest share of the water budget that is diverted for consumptive use. Based on our simulation estimates, the net irrigation water requirement (NIWR) for the basin is $65.07 \mathrm{~km}^{3} /$ year, which translates to a $13 \%$ decrease in the mean annual streamflow at the outlet.

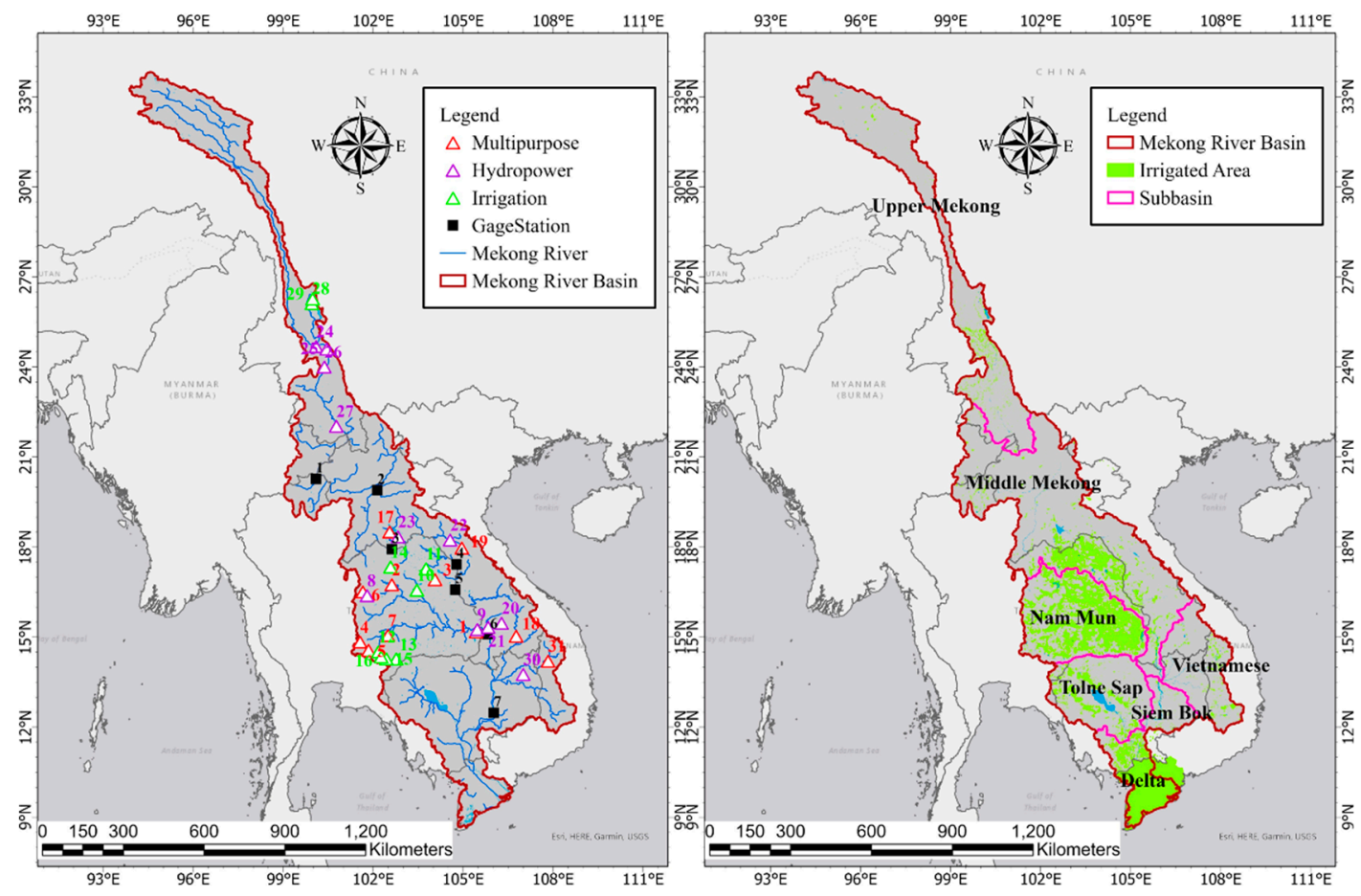

Figure 1. The Mekong River Basin, including irrigated areas and various types of dams.

Irrigated wet season rice is grown all year and fish catch (4.4 million tons per year) ensures regional and global food security. Furthermore, the river basin's hydropower potential exceeds $88,000 \mathrm{MW}$, with only a small portion of it being utilized $[9,28]$. For simulating the hydrologic budget, including streamflow, evapotranspiration, and soil moisture, macroscale hydrological models have been commonly used in this basin [16,29]. However, modeling the feedbacks between human and water systems that are quite intricate in this basin requires a dynamic systems framework, which would also require periodic revisions as the demand and supply scenarios are changing in the basin. For example, determining whether massive peaks in the wet season and their timing remain unaltered or whether seasonality in flows remains unaffected by hydropower and irrigation projects. For example, in order to develop policies for adaptation and resilience to natural and man-induced changes to rivers, large-scale hydrologic interconnections that take human abstractions into account must be used in the context of regional or continental assessments of the water cycle. We hypothesize that human-induced changes to the hydrologic cycle are evident. When water is taken out of a river for other purposes such as irrigation, water supplies, hydropower, ecological needs, and so on, the water budget in the natural system is completely altered. Because the river system is a continuum, the impact on the upstream portion of the watershed has a teleconnection to the downstream processes. It is critical that these processes be incorporated into a modeling framework 
in order to quantify the water budget. At the system level, feedback between different components is used to assess the consequences of evolving supply and demand conditions. However, our approach to modeling the Mekong River Basin (MRB) has been a hybrid of simulating natural flow without any interventions and integrating them in a systems modeling framework that takes into account demand for irrigation, hydropower, industrial, and municipal use as well as supply scenarios. This approach is required by the newly emerging socio-hydrology field for managing water resources in basins where the foodenergy-water nexus is clear and human and water systems are inextricably linked.

Since the MRB spans over six countries, the systematic collection of the hydrological, ecological, meteorological, and geographical datasets took 40 years of effort through the appointment of the Mekong River Commission (MRC) [30]. The Mekong agreement aims to achieve sustainable development through the real-time sharing of data and information for planning and monitoring purposes, but information-sharing is limited [31,32]. Moreover, the Lower Mekong Basin (LMB) has been noted to have a limited monitoring framework and is also ineffective in data and information sharing [31-36].

\section{Methodology}

\subsection{Study Area and Data}

The study examines 31 dams located throughout the MRB that control the flow of the river's mainstem and tributaries. The selection of the dams for the study was taken from the 187 dams in the basin on the basis of the purpose and availability of the available storage variation information from the Royal Irrigation Department, Thailand, or reservoir surface area variation information from the Global Lake Dynamics Database for Reservoirs (GLADD-R) [9,37]. The dams commissioned for irrigation, hydroelectricity generation, and municipal and industrial water diversions were chosen for the analysis since the goal is to investigate sustainable management of water supply for various sectors. Multipurpose, irrigation, and hydroelectric dams in Thailand (16 dams), Laos (7 dams), China (6 dams), Cambodia (1 dam), and Vietnam (1 dam) were chosen. The geographical location and details of the dams are provided in Figure 1 and Table 1, respectively.

The MRC website (http:/ / www.mrcmekong.org (accessed on 29 June 2021)) provides static dam characteristics such as location, year of completion/operation, dam height (m), reservoir storage capacity $\left(\right.$ million $\left.\mathrm{m}^{3}\right)$, reservoir area $\left(\mathrm{km}^{2}\right)$, installed capacity $(\mathrm{MW})$, and yearly energy generation (GWh). From 2001 to 2015, the monthly variation in reservoir surface area was computed using the Global Lake Dynamics Database for Reservoirs (GLAD Figure 1 and Table 1 show D-R) and reflectance images from LandSat8 and Sentinel2. The rule curve is based on the surface area variation and observed storage variation available in the Royal Irrigation Department (RID) reservoir database from 2006 to 2019.

The MRC supplied monthly mean observed streamflow data at mainstem gage stations from 1986 to 1998. Additionally, from 2006 to 2019, the Royal Irrigation Department (RID) reservoir database in Thailand (http:/ /app.rid.go.th:88/reservoir/ (accessed on 29 June 2021)) was used to collect daily observed inflow and outflow data of the dams. The FAO's AQUASTAT Global Information System on Water and Agriculture database was used to collect the observed volume of water used for irrigation at the country level for Thailand in 2007. The GFSAD Crop Mask for 2010 was used to calculate the MRB's irrigated area. The semi-distributed, physically based Variable Infiltration Capacity (VIC) model [38] routed by Lohmann et al. [39,40], is used to simulate the water volume at different river reaches as well as inflow to the dams. Furthermore, Haddeland et al. [41] used the VIC model to simulate the irrigation's monthly water consumption (Section 3.3). The overall water demand for drinking and industrial uses from the dam is calculated using data from the province's population from the MRC's Social Atlas of the LMB [42]. Municipal and industrial water demands are anticipated to be $5 \%$ and $1 \%$ of total volume for dams located in provinces with populations of more than 750,000 people, respectively. The Social Atlas of the LMB forecasts population growth of 0.5 to 3.5 percent per year between 2021 and 2099. The system dynamics model, which incorporates scenario analysis and optimization 
of water distribution between different sectors, is used to simulate the dam operation and outflow from the reservoir (Section 3.5). The hydropower generation from a dam was estimated as follows:

$$
H P=n \eta \rho q g h
$$

where $n$ is the number of turbines, $\eta$ is the dimensionless efficiency of the turbine, $\rho$ is the density of water $\left(1000 \mathrm{~kg} / \mathrm{m}^{3}\right), q$ is the volumetric flow rate $\left(\mathrm{m}^{3} / \mathrm{s}\right), g$ is the acceleration due to gravity $\left(9.81 \mathrm{~m} / \mathrm{s}^{2}\right)$, and $h$ is the height between inlet and outlet $(\mathrm{m})$.

Table 1. Details of the dam considered in the study are available at the MRC webpage (http://www.mrcmekong.org (accessed on 29 June 2021)), which show the location of the dams, year of completion/operation, dam height (m), reservoir storage capacity $\left(\right.$ million $\left.\mathrm{m}^{3}\right)$, reservoir area $\left(\mathrm{km}^{2}\right)$, and purpose of the dam.

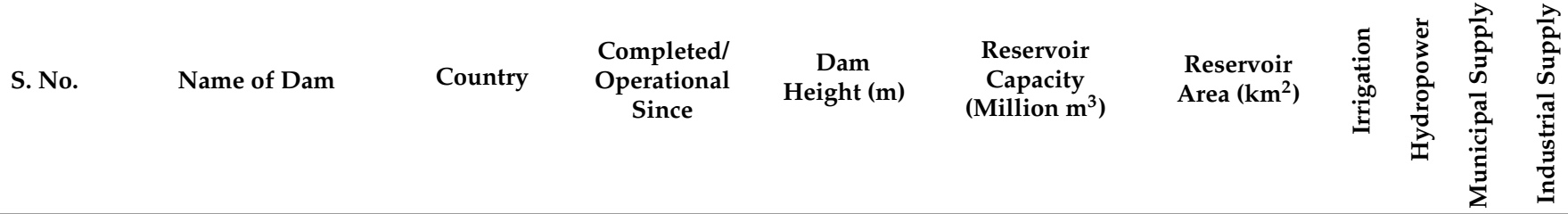

\begin{tabular}{|c|c|c|c|c|c|c|c|c|c|c|}
\hline 1 & Sirindhorn & Thailand & 1971 & 42 & 1966 & 288 & $x$ & $x$ & $\mathrm{x}$ & $\mathrm{x}$ \\
\hline 2 & Ubol Ratana & Thailand & 1966 & 32 & 2.559 & 41 & $x$ & $x$ & $\mathrm{x}$ & $\mathrm{x}$ \\
\hline 3 & Nam Pung & Thailand & 1965 & 40 & 165 & 2.165 & $x$ & $x$ & $\mathrm{x}$ & $\mathrm{x}$ \\
\hline 4 & Lam Takhong & Thailand & 1969 & 40.3 & 310 & 3.7 & $\mathrm{x}$ & $x$ & $\mathrm{x}$ & $\mathrm{x}$ \\
\hline 5 & Lam Phra Phloeng & Thailand & 1970 & 50 & 110 & 1.31 & $\mathrm{x}$ & $x$ & $\mathrm{x}$ & $\mathrm{x}$ \\
\hline 6 & Chulabhorn & Thailand & 1972 & 70 & 188 & 31 & $\mathrm{x}$ & $x$ & $\mathrm{x}$ & $\mathrm{x}$ \\
\hline 7 & Lam Chang Han & Thailand & 1992 & 18 & 26 & 4.8 & $x$ & $x$ & $\mathrm{x}$ & $x$ \\
\hline 8 & Huai Kum & Thailand & 1982 & 36 & 22.8 & 1.8 & & $x$ & $\mathrm{x}$ & $\mathrm{x}$ \\
\hline 9 & Pakmun & Thailand & 1994 & 17 & 114.3 & 1.7 & & $x$ & $\mathrm{x}$ & $\mathrm{x}$ \\
\hline 10 & Lam Pao & Thailand & 1969 & 33 & 1430 & 240 & $x$ & & $\mathrm{x}$ & $\mathrm{x}$ \\
\hline 11 & Nam Un & Thailand & 1973 & 29.5 & 520 & 8.5 & $x$ & & $\mathrm{x}$ & $x$ \\
\hline 12 & Upper Mun & Thailand & 1980 & 32.7 & 141 & 1.275 & $x$ & & $x$ & $\mathrm{x}$ \\
\hline 13 & Lam Nang Rong & Thailand & 1982 & 23 & 150 & 11.6 & $x$ & & $x$ & $x$ \\
\hline 14 & Huai Luang & Thailand & 1984 & 12.5 & 113 & 3.2 & $\mathrm{x}$ & & $\mathrm{x}$ & $x$ \\
\hline 15 & Lam Plai Mas & Thailand & 1988 & 32 & 98 & 1.04 & $x$ & & $\mathrm{x}$ & $x$ \\
\hline 16 & Lam Sae & Thailand & 1998 & 29.5 & 275 & 2.95 & $x$ & & $x$ & $x$ \\
\hline 17 & Nam Ngum & Laos & 1985 & 75 & 4700 & 370 & $x$ & $x$ & & \\
\hline 18 & Houay-Ho & Laos & 1998 & 80 & 3530 & 37 & $\mathrm{x}$ & $\mathrm{x}$ & & \\
\hline 19 & Nam Leuk & Laos & 2000 & 51.5 & 185 & & $x$ & $x$ & & \\
\hline 20 & Xeset 1 & Laos & 1991 & 18 & 30 & 0.1 & & $x$ & & \\
\hline 21 & Selabam & Laos & 1993 & 3.7 & 30 & & & $x$ & & \\
\hline 22 & Theun-Hinboun & Laos & 1998 & 27 & 20 & & & $\mathrm{x}$ & & \\
\hline 23 & Nam Mang 3 & Laos & 2004 & 22 & 49.43 & 10.2 & & $\mathrm{x}$ & & \\
\hline 24 & Xiaowan & China & 2010 & 292 & 15,043 & 190 & & $x$ & & \\
\hline 25 & Manwan & China & 1995 & 132 & 662 & & & $x$ & & \\
\hline 26 & Dachaoshan & China & 2004 & 111 & 933 & & & $x$ & & \\
\hline 27 & Jinghong & China & 2008 & 108 & 1233 & 510 & & $x$ & & \\
\hline 28 & Cibihe (Zibihe) & China & & & 93.22 & 7.9 & $x$ & & & \\
\hline 29 & Haixihai & China & & & 61.854 & 4 & $x$ & & & \\
\hline 30 & Ochum & Cambodia & 1993 & 10 & 1 & & & $x$ & & \\
\hline 31 & Yaly & Vietnam & 2002 & 69 & 1037 & 64.5 & $x$ & $x$ & $x$ & $\mathrm{x}$ \\
\hline
\end{tabular}




\subsection{The Variable Infiltration Capacity (VIC) Model}

The semi-distributed, physically based Variable Infiltration Capacity (VIC) model [38] with a $0.05^{\circ}$ spatial resolution uses the water balance and energy balance equations to convert precipitation to streamflow. Precipitation, minimum and maximum temperatures, and wind speed available at $0.25^{\circ}$ spatial and daily temporal resolution from the Global Meteorological Forcing Dataset (GMFD), the Climate Hazards Group InfraRed Precipitation with Station (CHIRPS), and the Climate Prediction Center (CPC) gridded datasets are among the meteorological parameters used to run the model [43]. The GMFD dataset was statistically downscaled to a $0.05^{\circ}$ spatial resolution from 1981 to 2016 . The GMFD dataset was developed by assembling various reanalysis and observed datasets such as the NCEPNCAR reanalysis [44], CRU TS3.0 [45], the GPCP [46], the TRMM [47], and the NASA Langley SRB [48]. Precipitation and temperature data for the recent period (2017-2019) was derived from the Climate Hazards Group InfraRed Precipitation with Station (CHIRPS) and the Climate Prediction Center (CPC) gridded dataset, respectively. The vegetation variability inside a grid cell is calculated as the fractional value of the grid covered by the specific vegetation class. The Advanced Very High-Resolution Radiometer (AVHRR) was used to create vegetation data, which includes land cover type, leaf area index, and albedo, with a spatial resolution of $1 \mathrm{~km}$. The energy balance equation at the land surface for each land cover type within the grid cell includes sensible heat, ground heat, ground heat storage, outgoing longwave and indirectly latent heat. The surface energy balance was closed through an iterative process which tries to find the surface temperature that yields surface energy fluxes to balance the incoming solar and longwave radiation fluxes. The water and energy balances are linked through the latent heat flux. In addition, the top two soil layers respond swiftly to rainfall, with diffusion from the middle to the top layer, while the bottom soil layer corresponds to the Arno model baseflow [49]. To extract soil properties, pedo-transfer functions [50] were applied to the Harmonized World Soil Database (HWSD) and merged with the soil class from the United States Department of Agriculture (USDA) classification. The sum of evaporation from bare soil and canopy, as well as transpiration from vegetation features, was computed using the Penman-Monteith technique weighted by the coverage fraction for each surface cover class and as a function of net radiation and vapor pressure deficit. The maximum canopy evaporation was based on the soil layer water intercept, architectural resistance, aerodynamics resistance, and the potential evaporation from a surface based on the Penman-Monteith equation with the canopy resistance set to zero. Because VIC is a one-dimensional hydrologic model, the fluxes are only exchanged vertically, implying that the interaction between adjacent grids is minimal. The variable infiltration curve [51] is a non-linear function of the fractional saturated area and was used to define water infiltration into the soil layer. Only the fluxes for each grid at a daily temporal resolution are provided by the VIC model, which are routed by Lohmann et al. $[39,40]$ scheme to extract the accumulated effect at a specific location.

The calibration parameters are the infiltration curve parameter $\left(b_{i}\right)$, the soil layer depth (D), a fraction of maximum velocity of baseflow where non-linear baseflow begins $\left(D_{s}\right)$, and a fraction of maximum soil moisture where non-linear baseflow occurs $\left(W_{s}\right)$ with allowable ranges of $0.1-0.5,0.1-1.5,0-0.4$, and $0.5-1.0$, respectively. The VIC model was used in the MRB to evaluate reservoir operation [5,52], drought [3], land transformation, and hydrological impacts [53].

\subsection{Irrigation Scheme}

The net irrigation water requirement (NIWR) is the quantity of free accessible water that is required for stable agricultural productivity. To simulate crop water requirements, the Haddeland et al. [41] irrigation scheme embedded within the VIC model with the GFSAD Crop Mask [54] for the year 2010 is employed. The main objective of the irrigation scheme is to provide additional moisture to the water-stressed vegetation caused by limited soil moisture availability. When the top layer of soil moisture falls below the level at which transpiration is limited, the irrigation process kicks in. At each computing step, 
the improved VIC model allows for irrigation water use depending on the expected soil moisture content for agricultural grid cells. Irrigation is represented in the model as additional precipitation when the soil moisture falls below the wilting point. The additional precipitation will continue every day until the soil moisture reaches field capacity [55]. The free-irrigation module of the irrigation scheme was used in this study, which assumed an unlimited water supply.

\subsection{Climate Model}

The simulation for the future period (2021-2099) is based on predicted climatology from four global circulation models (GCMs) from two Representative Concentration Pathways (RCPs), 4.5 and 8.5, GFDL-ESM2M, IPSL-CM5A-LR, MIROC-ESM-CHEM, and NorESM1-M, respectively. The climate models were chosen based on a collection of wet/dry and cold/hot climate conditions defined by precipitation and temperature change for five future periods ranging from 2006 to 2099. Using the Intersectoral Impact Model Intercomparison Project (ISI-MIP) technique, the precipitation, minimum, and maximum temperatures from the GCMs were bias-corrected and statistically downscaled to 0.25-degree resolution [56].

\subsection{Mekong System Dynamics (MekSyD) Model}

The ideal distribution of available water was simulated using the Mekong System Dynamics (MekSyD) model for outflow, hydroelectric generation, and water supply to municipal and industrial sectors under observed and predicted conditions. GoldSim is a powerful and adaptable Windows-based system dynamics application that performs probabilistic simulations to assist in the management and decision-making of complex systems [57]. GoldSim propagates uncertainty in processes and parameters defined by the probability distribution and disruptive events throughout the model using Monte Carlo simulation. Based on the inflow, net irrigation water requirement, and domestic-industrial water demands, the model calculates hydropower generation and demand satisfaction for other sectors using the rule curve and depth-storage relationship. The model accounts for the human-induced changes in the river flow via the cascading effects of the dams as well as the naturally occurring loss from reservoir water evaporation (Figure 2). Two conditions were maintained for the release of outflow from reservoirs:

(a) The minimum monthly release is set as $10 \%$ of the monthly inflow to the reservoir;

(b) A minimum of $10 \%$ of the total capacity of reservoirs is maintained, as described by Liu et al. (2016) [58].

The operation of each reservoir changes depending on inflow conditions, which can be extremely high or extremely low. The flood and low-inflow magnitudes were estimated as the tenth and ninetieth percentiles of the flow duration curve developed using inflow data from 1950 to 2005, respectively. To be more specific, the water supply to the various sectors was modified under the following three conditions to ensure the reliability of the dam:

(a) When the inflow is less than the low-inflow magnitude, no water is supplied to any sector in order to accumulate water to increase reservoir storage. (b) When inflow exceeds the flood magnitude, the excess volume is spilled from the emergency spillway, and the remaining volume is used for reservoir operation. (c) When inflow is insufficient to meet the desired rule curve volume, water is only supplied to the environmental sector, with the remainder is stored in the reservoir. 


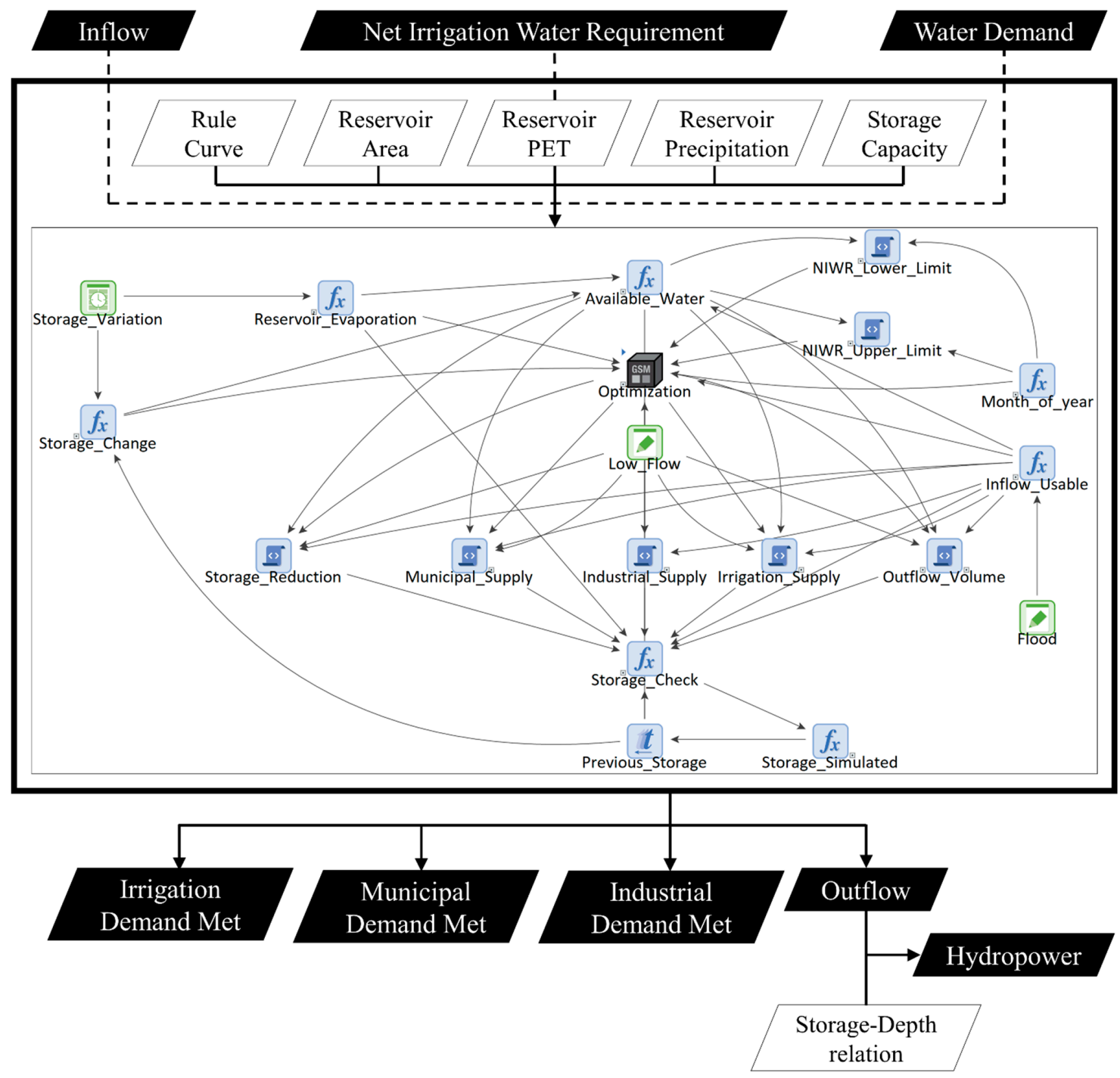

Figure 2. Schematic of coupled food-energy-water systems dynamics modeling using the MekSyD model for the MRB.

The Box complex method was used in the model to perform the optimization scheme for allocating water resources between demand from different sectors by defining the objective function and objective variables [59]. The objective function and constraints for the optimization of reservoir operation were expressed as:

Variables:

The following variables are involved in the model of the optimization of the reservoir:

i. $\quad Q^{h}$ : turbined flow;

ii. $Q^{I}$ : irrigation flow;

iii. $Q^{m}$ : municipal flow;

iv. $\quad Q^{\text {Ind }}$ : industrial flow;

v. $\quad S$ : volume stored in the reservoir;

vi. $\quad S^{\max }$ : maximal operational volume of the reservoir ( $95 \%$ of the storage capacity of the reservoir);

vii. $S^{\min }$ : minimal operational volume of the reservoir $(10 \%$ of the storage capacity of the reservoir);

viii. $h$ : height of the reservoir elevation, as a function of the stored volume;

ix. $I D$ : irrigation demand;

x. $\quad M D$ : municipal demand;

xi. IndD: industrial demand; 
xii. $\quad Q^{F}$ : water inflow into the reservoir;

xiii. I: inflow contribution from the catchment area;

xiv. $\quad \eta$ : efficiency of the turbine;

xv. $\quad Q_{\text {ecological }}^{D, \text { min }}$ : minimum downstream flow for sustaining the ecosystem $(10 \%$ of the inflow);

xvi. $\quad a, b, b^{\prime}$ : re-turbined water use factor.

Here, $Q^{h}, Q^{I}, a, b$, and $b^{\prime}$ are the decision variables.

Objectives:

To rationally and effectively use the water resources of a reservoir, a multiobjective optimization model is required that considers both water diversion and power generation objectives for reservoirs with water-diversion and power-generation tasks [60].

Maximize water distribution between water-demanding sectors based on the purpose of the dam:

$$
\text { maximize } f_{\text {objective }}=\left\{\begin{array}{cc}
Q^{h}+Q^{I}+Q^{m}+Q^{\text {Ind }} & \text { for wet season } \\
a * I D+b+Q^{m}+Q^{\text {Ind }} & \text { for dry season }
\end{array}\right.
$$

During the dry season, re-turbined water is used for irrigation supply $\left(Q^{I}\right)$ to meet up to $75 \%$ of water demand (ID), i.e., $a \in[0,0.75]$. The remaining available water is distributed based on the objective for the wet season as $b^{\prime}$ for hydropower and $b$ for irrigation. As a result, for the dry season:

$$
Q^{h}=a \times I D+b^{\prime} \quad \text { and } Q^{I}=a \times I D+b
$$

The annual energy generation from the reservoir is estimated as:

$$
\text { Energy }_{\text {hydropower }}=\sum_{\text {Jan }}^{D e c} Q_{t}^{h} \times h \times g \times \eta
$$

Constraints:

A. Water balance constraint:

$$
\begin{gathered}
S_{t+1}-S_{t}=\left(Q_{t}^{F}-Q_{t}^{h}-Q_{t}^{I}-Q_{t}^{m}-Q_{t}^{I n d}\right) \Delta t \\
\text { Cascading dams : } Q_{t}^{F}=\sum_{k=1, k \in U}^{N}\left(Q_{t, k}^{h}+I_{t}\right)
\end{gathered}
$$

Here, $U$ is the set of upstream reservoirs.

A. Storage of the reservoir constraint:

$$
S^{\min } \leq S_{t} \leq S^{\max }
$$

B. Irrigation supply constraint:

$$
0.8 \times I D \leq Q_{t}^{I} \leq I D
$$

C. Municipal supply constraint:

$$
0.8 \times M D \leq Q_{t}^{m} \leq M D
$$

D. Industrial supply constraint:

$$
0.8 \times \operatorname{IndD} \leq Q_{t}^{\text {Ind }} \leq \operatorname{IndD}
$$

E. Ecological demand constraint:

$$
Q_{\text {ecological }}^{D, \min } \leq Q_{t}^{h}
$$




\section{F. Nonnegative constraints.}

All values above are positive.

\subsection{Scenarios}

As evident from the increase in cropland area over forest land [16] and the practice of three crop cycles per year in Vietnam, the expansion of the irrigation area and inclusion of additional crop cycles in the MRB to meet the demand of the growing population is a real-world situation. The development of six scenarios corresponding to a $5 \%$ and $10 \%$ increase in irrigated area by incorporating two-crop cycles or three-crop cycles per year was used to investigate the response of the multipurpose and four irrigation dams under different conditions of agricultural expansion (Table 2). The 5\% scenario was generated based on the current trend of agricultural area growth, whereas the $10 \%$ scenario was the simulation of the exacerbation of demand for food. The planned third crop cycle consists of a sowing period from October to January, followed by a growth and harvesting period from February to May. The reference scenario (Scenario 1) is based on the current situation, namely, two annual crop cycles and the availability of water for irrigation from irrigation dams.

Table 2. Details of the scenarios considered to account for the increase in water demand by the irrigation sector based on irrigation area variation and crop cycle number per year.

\begin{tabular}{cccc}
\hline S. No. & Scenario & $\begin{array}{c}\text { Percentage Increase in the } \\
\text { Irrigation Area }\end{array}$ & $\begin{array}{c}\text { Number of Crop Cycles } \\
\text { per Year }\end{array}$ \\
\hline Scenario 1 & $0 \%$ increase with 2 cycles (Reference) & $0 \%$ & 2 cycles \\
\hline Scenario 2 & $5 \%$ increase with 2 cycles & $5 \%$ & 2 cycles \\
\hline Scenario 3 & $10 \%$ increase with 2 cycles & $10 \%$ & 2 cycles \\
\hline Scenario 4 & $0 \%$ increase with 3 cycles & $0 \%$ & 3 cycles \\
\hline Scenario 5 & $5 \%$ increase with 3 cycles & $5 \%$ & 3 cycles \\
\hline Scenario 6 & $10 \%$ increase with 3 cycles & $10 \%$ & 3 cycles \\
\hline
\end{tabular}

\subsection{Stress Index}

The system's extreme occurrences were defined by the magnitude of input to the reservoirs. Extremely high inflows greater than the tenth percentile flow value (flood events) and extremely low inflows less than the ninetieth percentile flow value (low-flow events) affect the system's ability to distribute water to diverse sectors. However, once the extreme events have passed, the system returns to normal operation. The impact and duration of the events determine the stress in the system induced by the occurrence of a single or sequence of extraordinary occurrences. The deficit volume during low flow events and surface volume during flood events were used to calculate the impact of extreme occurrences in comparison to long-term historic inflow volume. For each reservoir, the system's stress index for extreme occurrences is calculated as follows:

$$
\begin{gathered}
\text { Stress Index } \text { Flood }=\max \left(\sum \frac{\text { Volume }_{\text {Flood }}-\text { Volume }_{\text {Average flow }}}{\text { Volume }_{\text {Average flow }}} d t\right) \\
\text { Stress Index }_{\text {Low flow }}=\max \left(\sum \frac{\text { Volume }_{\text {Average flow }}-\text { Volume }_{\text {Low flow }}}{\text { Volume }_{\text {Average flow }}} d t\right)
\end{gathered}
$$

The flood event was defined as the months when the inflow exceeds the amount that is expected to occur $90 \%$ of the time. Low-flow events were defined as months with inflow less than the volume, which occur $10 \%$ of the time. The stress index depicts the magnitude of flow volume fluctuations compared to the average flow that the dams are expected to withstand during continuous or discrete extreme events. The stress index was estimated for 
the dams for four time periods between 2021 and 2099: 2021-2040, 2041-2060, 2061-2080, and 2081-2099.

\section{Results and Discussion}

\subsection{Future Projections}

In comparison to the historic period (1950-2005), with a mean daily precipitation of $4.16 \mathrm{~mm}$ /day, a modest increase of $4.26 \mathrm{~mm} /$ day for RCP 4.5 and $4.25 \mathrm{~mm} /$ day for RCP 8.5 is expected in the future (2006-2099). NorESM1 m predicted the greatest increase in precipitation in the basin, while GFDL-ESM2M predicted a decrease. Except for February and May, all months were expected to see an increase in monthly precipitation. The historic mean annual precipitation was $1520 \mathrm{~mm}$, while the future mean annual precipitation was $1551 \mathrm{~mm}$ and $1548 \mathrm{~mm}$ under RCP 4.5 and RCP 8.5, respectively. The historic mean annual temperature was $22.2^{\circ} \mathrm{C}$, while the future mean annual temperature was estimated to be around $23.9^{\circ} \mathrm{C}$ and $24.7^{\circ} \mathrm{C}$ under RCP 4.5 and RCP 8.5, respectively. For RCP 4.5 and RCP 8.5 , average monthly temperature increases of $1.8^{\circ} \mathrm{C}$ and $2.6^{\circ} \mathrm{C}$ were projected between now and the end of the century, respectively. The month of April was expected to see the greatest increase.

The annual streamflow at the gage station locations was projected to increase between $3.7 \%$ and $5.2 \%$ under RCP 4.5 , while the RCP 8.5 projected a reduction from $7.9 \%$ to $34.4 \%$ due to changes in projected precipitation. The historic inflows to the dams varied from $1942.1 \mathrm{~m}^{3} / \mathrm{s}$ (Jinghong, China) to $1.5 \mathrm{~m}^{3} / \mathrm{s}$ (Lam Plai Mas, Thailand). The percentage change in inflows ranged from $+25 \%$ to $+1.2 \%$ under RCP 4.5 , while under RCP 8.5 , the change ranged from $-28.5 \%$ to $-74.7 \%$. However, the dams located in Thailand might experience a higher increase in inflow under RCP $4.5(12.9 \%)$, while Thailand dams could suffer the lowest decrease (55.6\%) under extreme temperature conditions (RCP 8.5). Similar flow variations might be experienced by Chinese dams with an average reduction in inflow of $52.4 \%$ under RCP 8.5 , but an increase in inflow of $6 \%$ when compared to historic inflows. Dams in Laos PDR, Cambodia, and Vietnam were projected to experience similar flow conditions under climate change, with an average increase in inflows of $3.7 \%$ under RCP 4.5 and a decrease of $31.7 \%$ under RCP 8.5 .

Dams were classified based on their inflow magnitude as very low flow, low flow, high flow, and very high flow classes with a peak flow of $10 \mathrm{~m}^{3} / \mathrm{s}, 100 \mathrm{~m}^{3} / \mathrm{s}, 800 \mathrm{~m}^{3} / \mathrm{s}$, and $2500 \mathrm{~m}^{3} / \mathrm{s}$, respectively. In general, the summer season (March-May) was expected to experience a significant decrease in flows. The streamflow at the gage station locations might decrease by $5.8 \%$ and $17.8 \%$ in the future under RCP 4.5 and RCP 8.5 , respectively, when compared to the historic period. In addition, the inflow to very low flow class dams could reduce by $13.5 \%$ under RCP 4.5 and $6.1 \%$ under RCP 8.5 . Similarly, the future decrease for the low flow, high flow, and very high flow dams was expected to be $11.4 \%(9 \%), 8.8 \%$ $(12.3 \%)$, and $1.5 \%(14.8 \%)$ under RCP 4.5 (RCP 8.5$)$ with respect to long-term historic flows. On the other hand, the gage station locations were expected to see an increase in projected streamflow during the monsoon season, accounting for $5.8 \%$ under RCP 4.5 and a marginal decrease of $0.8 \%$ under RCP 8.5 . While the dams might experience an increase in inflows following the monsoon season (October-February), the increase in inflow for the very low flow dams could be $19 \%$ and $28.9 \%$ through October-February in the future under RCP 4.5 and RCP 8.5 , respectively. Furthermore, future inflows to low flow and high flow dams could increase by $11.2 \%$ and $7.8 \%$ under RCP 4.5 , and $12.9 \%$ and $8.6 \%$ under RCP 8.5 , compared to historic inflows. However, future inflows to very high flow dams could differ under RCP 4.5 and RCP 8.5 with a change of $+6.1 \%$ and $-9.6 \%$, respectively. In conclusion, the impacts of climate change were evident from a seasonal effect on dam inflows, with surplus inflow volume following the monsoon season and dry flows during the summer period.

The net irrigation water requirement for the future period was altered by the meteorological conditions in MRB, specifically modifying the evapotranspiration under the irrigation conditions. The MRB could witness a decrease of $0.3 \%$ and $0.2 \%$ in NIWR in 
the future under RCP 4.5 and RCP 8.5, respectively, when compared to the historic water requirement for irrigation. The NIWR was expected to decline in all months except the summer period, i.e., March-May; however, the decrease was expected to be the highest during the monsoon season, i.e., July-October. The average decrease in the monsoon season in NIWR might account for $0.75 \%$ and $0.89 \%$ of the MRB under RCP 4.5 and RCP 8.5, respectively. In contrast, the NIWR for the future period could increase by $0.7 \%$ and $0.98 \%$ during the summer season under RCP 4.5 and RCP 8.5, respectively. A similar pattern of the NIWR change in the future under climate change could be seen in the Delta, Siem Bok, Vietnamese, and Middle Mekong subbasins. On the other hand, the Upper Mekong and Mun Chi basins were expected to show an increase in NIWR throughout the year. Specifically, the increase in the NIWR during the summer season could be $6 \%$ and $9.7 \%$ under RCP 4.5 and RCP 8.5, respectively for the Upper Mekong. Similarly, the increase in the Mun Chi basin was expected to be $8.3 \%$ and $12.5 \%$ during the summer season under RCP 4.5 and RCP 8.5 , respectively. Moreover, the seasonal variation of the NIWR for the MRB and subbasins could be similar to the historic period in the future.

The mean annual NIWR over the historic period was estimated to be 60,970 million $\mathrm{m}^{3}$ for the Mekong river basin, with the Delta and Middle Mekong subbasins accounting for the lion's share. The Delta region was expected to have the greatest decrease in projected NIWR, ranging between $0.46 \%$ and $0.58 \%$ for RCP 4.5 and RCP 8.5 , respectively. The projected NIWR for Vietnamese and Siem Bok was expected to fall by $0.2 \%$ and $0.3 \%$, respectively, under RCP 4.5 and RCP 8.5, respectively. However, under RCP 4.5 and RCP 8.5 , the NIWR was projected to rise by $3.8 \%$ and $6.4 \%$, respectively, compared to the historic mean for the Upper Mekong and Mun Chi subbasins. Tonle Sap could experience a positive change in the projected NIWR with a nominal increase of $0.04 \%$ under RCP 4.5 and $0.17 \%$ under RCP 8.5 . The change for the Middle Mekong was expected to be $-0.85 \%$ and $+0.23 \%$ for the future period under RCP 4.5 and RCP 8.5 , respectively.

\subsection{Stress Index}

An enormous surge in the inflow during the flood events and extreme deficit during the drought events disrupts the operation of the reservoir in fulfilling the water demands of the different sectors. The disproportionate inflow volumes during the extreme events cause the reservoirs to operate to the upper or lower limits of the rule curve.

The stress index of the MRB dams for flood and low flow events during the four timespans; 2021-2040, 2041-2060, 2061-2080, and 2081-2099, using four climate models under RCP 4.5 and RCP 8.5, is shown in Figure 3. The flood events are expected to have a significant impact on the dams, depending on their location in the MRB. The dam operation will be difficult for resisting stress due to flood occurrences during the years 206-2099. In the years 2061-2080, the flood stress index will average 5.81, compared to 5.05, 4.67, and 4.57 in the years 2081-2099, 2041-2060, and 2021-2040, respectively (Figure 3). Despite the fact that Thailand's dams will be subjected to 6.7 times the average inflow during flood events from 2061 to 2099, the Lam Nang Rong, Upper Mun, and Lam Chang Han will be subjected to the most stress, with stress indexes of $8.81,8.73$, and 8.55 , respectively. The Lam Plai Mas, Manwan, Dachaoshan, Jinghong, and Yaly, on the other hand, will not be stressed for supplementary flows during some periods. With a stress index of less than 3, flood events will have the least impact on China and Vietnam, while Laos and Cambodia will have a moderate impact with a stress index of around 5, but Thailand will undergo flood stress accounting for 6.26 times the average flow volume. Flow volume will increase by 7.13 times in Thailand, 5.54 times in Laos, 3.31 times in China, and 2.86 times in Vietnam during 2061-2080, while Cambodia will have the worst floods during 2021-2040, with a stress index of 5.47 compared to the other periods. 


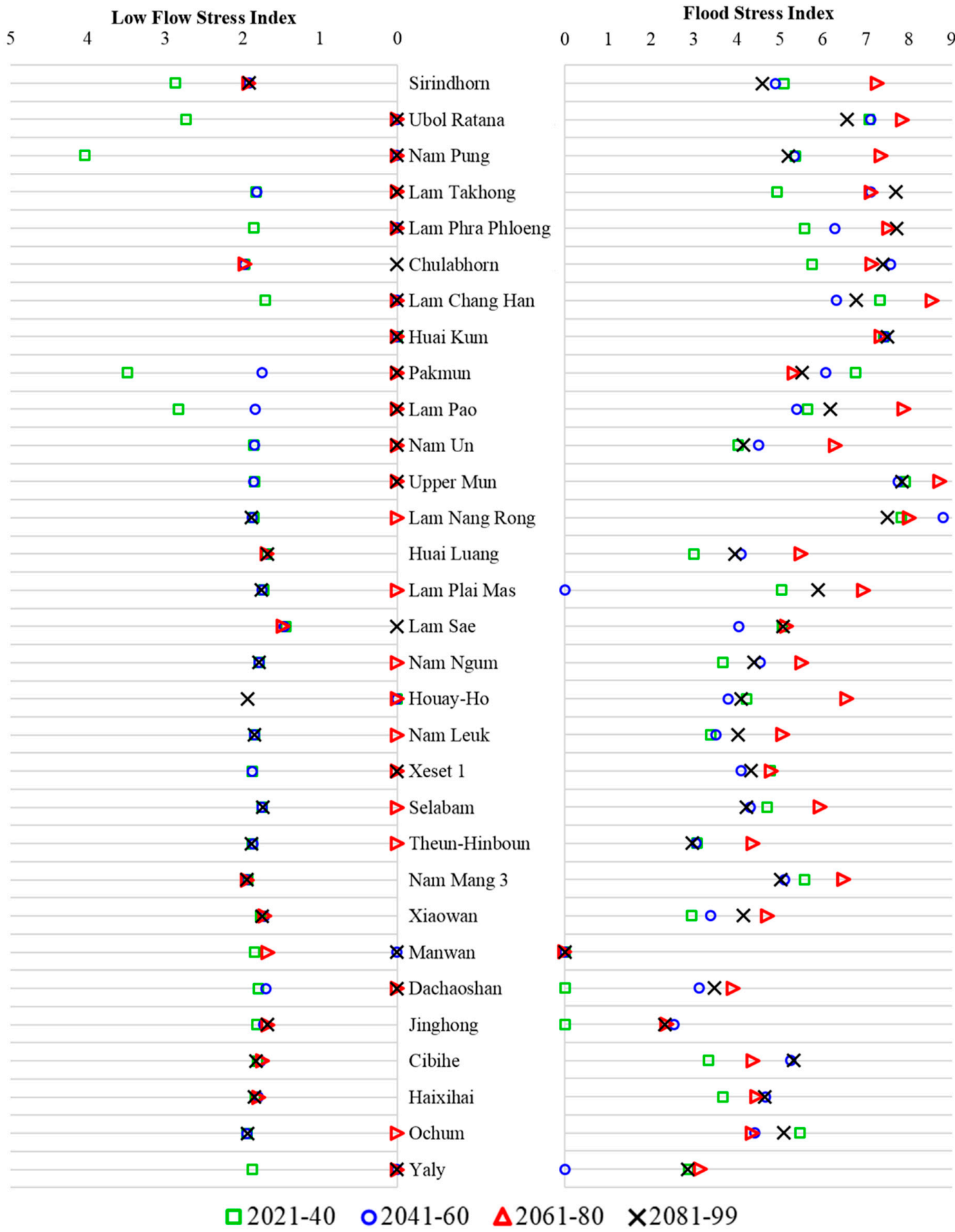

Figure 3. Stress index of the MRB dams for flood and low flow events during the four timespans; 2021-2040 (green square), 2041-2060 (blue circle), 2061-2080 (red triangle), and 2081-2099 (black cross) using four climate models under RCP 4.5 and RCP 8.5.

Low-flow events, on the other hand, are expected to harm dams across the MRB's five member countries. Low-flow events have a lower impact when compared to flood events, which have a stress index of 1.18. Low-flow events have a greater impact during 2021-2060, with a stress index of 1.92 and 1.34, respectively, while the index drops to 0.57 and 0.88 during 2061-2080 and 2081-2099, respectively. Most dams have a low-flow stress index of 0 to 2, although Lam Takhong, Pakmun, Sirindhorn, Lam Pao, and Ubol Ratana have a stress index higher than 2.75 between 2021 and 2040. During the years 2061-2099, the majority of dams in Thailand and Laos were predicted to be unaffected by the low flow. The low-flow stress index for dams in China and Cambodia is 1.47, whereas index values for Laos and 
Thailand were 1.26 and 1.06, respectively. Stress index values for Vietnamese dams are less than 0.5. Low flow has the greatest impact on all member nations between 2021 and 2040, with an index value of 2.11 for Thailand, 1.94 for Cambodia, 1.87 for Vietnam, 1.81 for China, and 1.58 for Laos.

The estimated occurrence times of the five extreme flood and low-flow events between 2021 and 1999 are shown in Figure 4. Extreme flood events are expected to occur in the second half of the century, with the majority of low-flow events occurring between 2021 and 2050. Thailand, Laos, and China are predicted to follow a similar pattern, with the largest flood events occurring in 2063-2074, 2055-2081, and 2064-2089, respectively, while Cambodia and Vietnam would see the highest flow in 2031-2060. The driest low-flow events, on the other hand, are projected in Thailand from 2037 to 2045, Laos from 2029 to 52, China from 2040 to 80, and Cambodia and Vietnam until 2067. Dam stress signifies the degree in the modification of the reservoir operation to accommodate the projected excess flow volume during the flood event and deficit flow available during the low-flow events without imposing a significant threat to the various sectors and ecosystem. The dam stress helps to analyze the situation when the purpose of the dam is questionable due to low flows that cannot be meet contractual obligations and avoid disruptions. This kind of scenario analysis helps mitigate impending crisis with water resources and prevent associated negative consequences due to low flows.

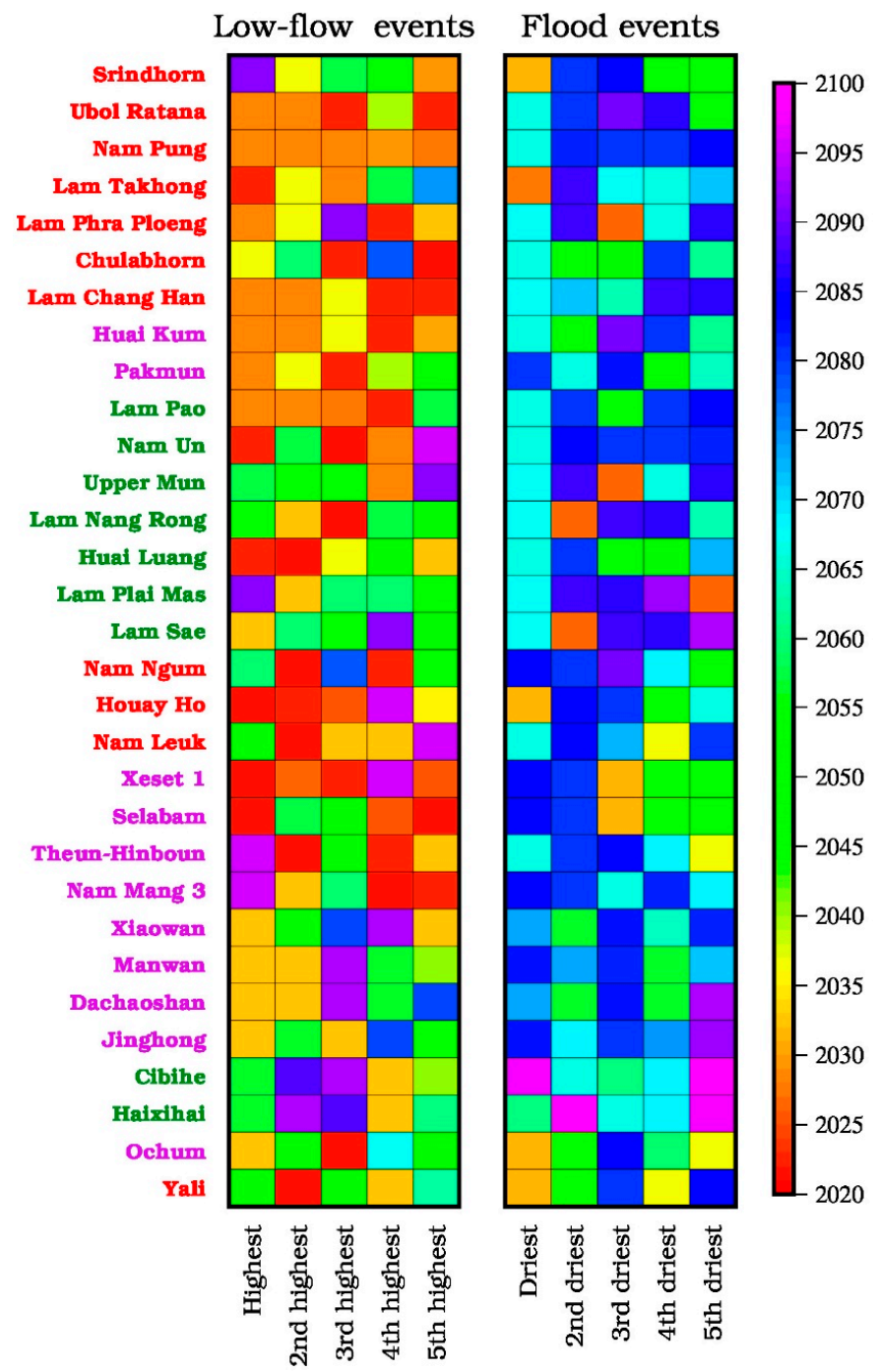

Figure 4. The projected year of occurrence of the extreme five flood events and driest low flow events for the MRB dams between 2021 and 2099 using four climate models under RCP 4.5 and RCP 8.5. 


\subsection{The Tradeoff between Energy and Irrigation Sectors}

The impact of increasing agricultural land ( 5 percent- 10 percent) and intensifying irrigation operations (2-crop or 3-crop cycles per year) on the hydropower generation of multipurpose dams was investigated using six different scenarios (Table 2). The impact of competitive water demand from one industry over another in the MRB over time is shown in Figure 5. Any rise in net irrigation water demand has a direct influence on the multipurpose dams' electricity generation, given the expected scenarios of variable inflows. Even if the increased water demand under two scenarios of increased area $(5 \%$ and $10 \%)$ and an additional crop every year is not totally supplied, the irrigation water supply of 80 percent to 95 percent can result in a $20 \%$ reduction in hydropower generation.

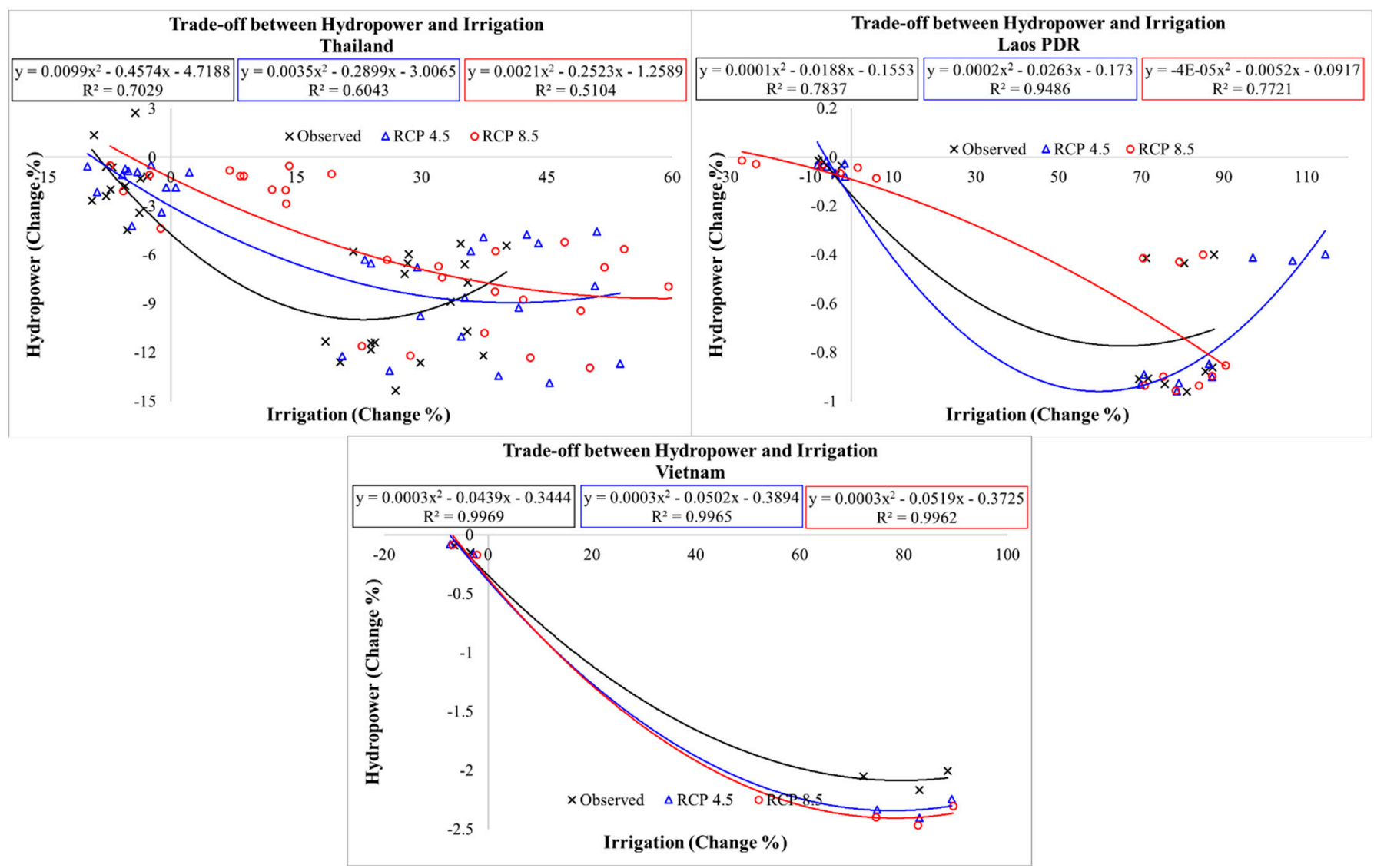

Figure 5. A tradeoff between the energy (\% change) and irrigation ( $\%$ change) sectors based on the six scenarios of agricultural expansion for the multipurpose dams in the MRB for the observed (black) and future period under RCP 4.5 (blue) and RCP 8.5 (red). The slope, equation, and goodness of fit of a linear trendline are estimated (R2).

Based on the total amount of water available in the reservoirs, the increase in irrigation supply for an additional crop cycle is 10 times more than the supply for a $5-10 \%$ area growth across two crop cycles per year. Multipurpose dam energy generation was reduced by $0.8 \pm 0.9 \%$ ( -7 to $130 \mathrm{GWh}$ ) when the irrigated area is increased, but energy generation is reduced by more than $5 \pm 3 \%$ (150-650 GWh) when a crop cycle was added. The disruption in hydropower generation caused by the irrigation sector was greatest for multipurpose projects in Thailand. Under RCP 4.5, the energy sector is expected to lose 0.15 percent of its hydropower generation for every percent increase in irrigation supply, while under $\mathrm{RCP} 8.5$, the energy loss is expected to be 0.13 percent for every percent increase in irrigation supply. The dams in Laos and Vietnam, on the other hand, will have no effect on the energy sector. Under RCP 4.5 and RCP 8.5, hydropower generation is expected to decrease by 0.006 percent and 0.007 percent for each percent increase in irrigation supply for Laos PDR 
dams. Furthermore, the Vietnamese multipurpose dams will suffer a loss of $0.025 \%$ for every percent increase in irrigation supply in the future.

During the observed period, the multipurpose dams generated 316 GWh of annual energy generation, accounting for $97 \%$ of the demand and satisfying more than $60 \%$ of the water demand from the irrigation, municipal, and industrial sectors. Similar efficiency was observed for irrigation dams, which supply more than $60 \%$ of irrigation water demand and $50 \%$ of municipal and industrial demand. The hydropower dams generated $35 \%$ more energy than required, resulting in an annual generation of $2863 \mathrm{GWh}$ while meeting more than $80 \%$ of the municipal and industrial sectors' water demands. Climate change has a positive impact on dam performance, with an increase of $35 \%$ and $32 \%$ in energy generation during 2021-2009 under RCP 4.5 and RCP 8.5, respectively, when compared to the observed period (Figure 6). Furthermore, under RCP 4.5, the increase in water demand met for irrigation, municipal, and industrial sectors is projected to be $7.4 \%, 6.5 \%$, and $8.1 \%$, respectively, under RCP 4.5. Similarly, under RCP 8.5 , the dams are expected to meet increased demand with a $6.1 \%$ increase in irrigation demand and a $6.65 \%$ increase in municipal and industrial water demands.

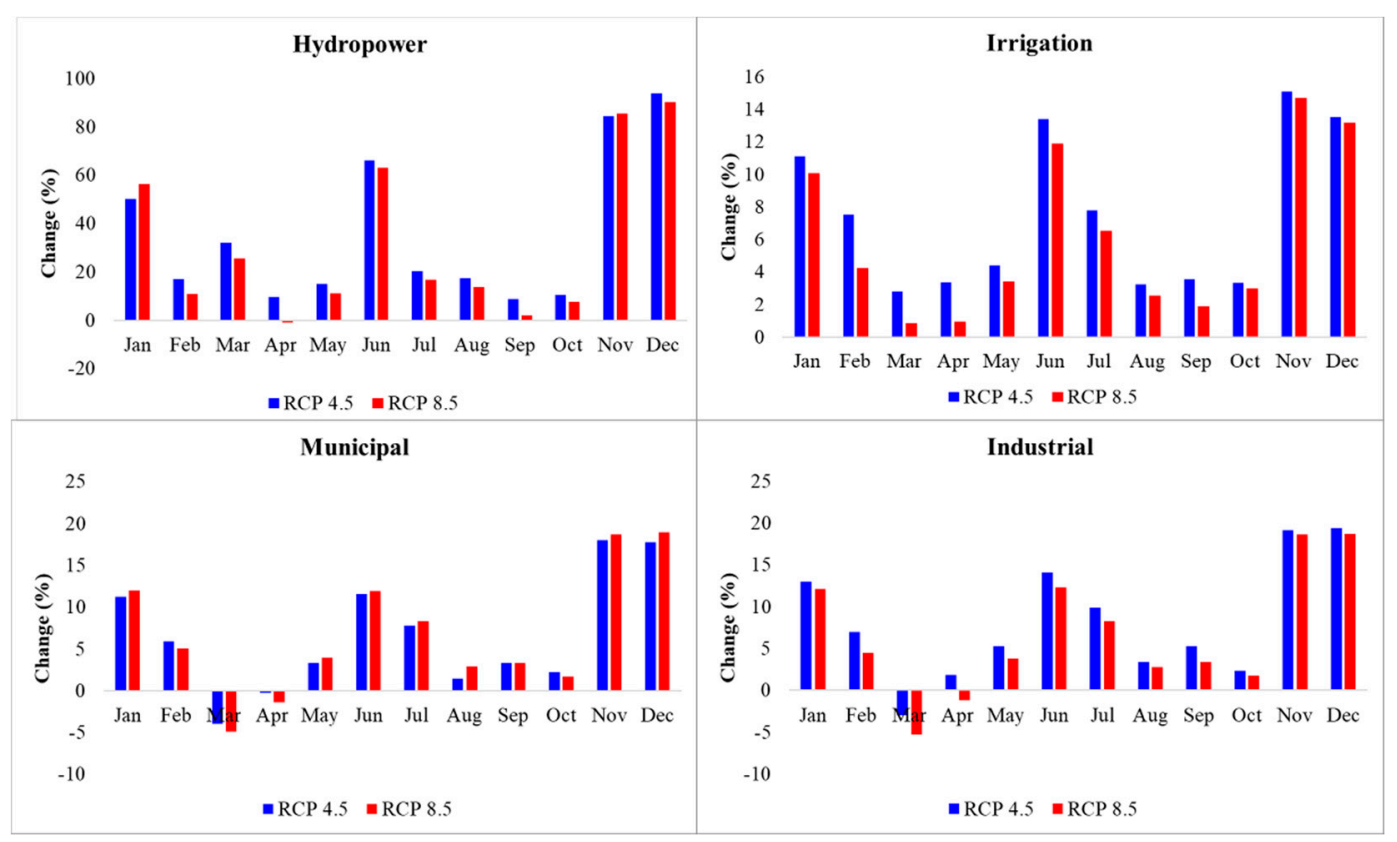

Figure 6. Changes in energy generation (GWh), as well as the percentage of demand met by dams from the irrigation, municipal, and industrial sectors from 2021 to 2099 as a result of climate change, as calculated using four climate models under RCP 4.5 and RCP 8.5 .

The benefit of feedback analysis: With constraints introduced in the MekSyD model, we are able to accommodate hydrologic extremes and appropriate the availability of water under high- and low-flow conditions, and ensure water supply throughout the year through rule curves by dividing water for ecological considerations apart from human extractions. By allowing minimum storage conditions based on the inflows, we maintain the integrity of dam operations at all times. With the non-stationarity that we considered in the analysis and coupled human-induced and natural variability, the tool can be of use for any additional scenarios or factors that may impact the economy and livelihoods in the basin. Through the optimal operation of the reservoir, we find that additional irrigation requirements with the increased irrigation areas can be met while also safeguarding the hydropower generation targets and environmental flow requirements. However, for practical use of these results, policy perspectives across the basin countries should be transparent and agreed upon for developing water development projects with due geopolitical considerations. The operation of the reservoirs is crucial during low flow periods (February-April) because 
any mismanagement can lead to the devastation of the water supply to various sectors due to the availability of marginal water for supply. The policies should be flexible enough so that the basic framework of distribution between states is maintained.

The uncertainty in the projected inflows, energy generation, and water diversion for different purposes generates from employing four climate models under two scenarios (eight ensemble members) to encompass the various range of precipitation and temperature conditions. In addition, the selection of the reservoir for the analysis is limited by the availability of the surface area variation data from GLADD-R for the development of the rule curve [37]. The reservoir with a surface area of less than $1 \mathrm{~km}^{2}$ cannot be included in the analysis. Additionally, the lack of observed inflow data for dams outside Thailand and irrigation water requirements hindered the validation of the results.

\section{Conclusions}

Integrated evaluation of river basins is a well-known concept; nevertheless, changes in coupled human-natural systems in basins with rapid development necessitate new tools, data, and approaches for long-term river basin development and management. In managed basins, such as the MRB, the distributed nature of anthropogenic-induced changes requires dynamic feedback analysis between human and water systems at local scales so as to improve the predictability of the system behavior over long time scales and large spatial scales. Traditional supply and demand analysis takes into consideration basin transformations due to natural and human-induced climate changes, but it rarely considers human well-being, sustainability of the river basin, and societally relevant science.

In our systems analysis of coupled natural and human processes in the MRB, we identified the impact of extreme events and their stresses on the system as well as a potential expansion of irrigated areas to increase agricultural productivity, reliability of hydropower generation, and sustainability.

- The projected increase in precipitation from $4.16 \mathrm{~mm} /$ day to $4.26 \mathrm{~mm} /$ day and $2.1^{\circ}$ temperature rise will modify the inflow by $+13 \%$ to $-50 \%$ in the future, while a $0.25 \%$ (15.24 billion $\mathrm{m}^{3}$ ) reduction is projected for the Net Irrigation Water Requirement (NIWR). During the dry season, the shift in inflow and drop in NIWR is critical since the available water for supply is limited.

- The climate impact analysis reveals that the MRB is prone to extreme low flow events until 2060, while frequent flood events are expected towards the end of the century.

- The flood events will cause excessive stress on reservoir operations to handle up to six times more flow volumes; however, the low-flow events will marginally affect the system.

- In order to reinforce the farmers' drought concerns, the diversion of water for meeting $1 \%$ additional irrigation water supply will be reduced by $0.15 \%$ of the energy generation in Thailand.

- Climate change has a beneficial impact on dam performance, with an increase of $33 \%$ in energy generation, $6.8 \%$ in irrigation water supply, $6.6 \%$ in municipal water supply, and $7.4 \%$ in industrial supply between 2021 and 2099.

Recognizing disparities in water availability due to human impacts on the hydrologic cycle and identifying beneficiaries across the region provides some insights for transboundary rivers, but stakeholder-driven scenarios are required to apply these findings.

Author Contributions: Conceptualization, V.S.; Data curation, S.A.A.; Formal analysis, S.A.A.; Funding acquisition, V.S.; Investigation, V.S. and S.A.A.; Methodology, V.S.; Project administration, V.S.; Resources, V.S.; Software, S.A.A.; Supervision, V.S.; Writing—original draft, S.A.A.; Writingreview \& editing, S.A.A. and D.J.S. All authors have read and agreed to the published version of the manuscript.

Funding: This work was supported in part by NASA under the award 80NSSC17K0259. We also acknowledge the partial support received by the first author from the Virginia Agricultural Experiment 
Station (Blacksburg) and the Hatch Program of the National Institute of Food and Agriculture, the U.S. Department of Agriculture (Washington, D.C.).

Institutional Review Board Statement: Not applicable.

Informed Consent Statement: Not applicable.

Data Availability Statement: Not applicable.

Conflicts of Interest: The authors declare no conflict of interest.

\section{References}

1. Schelle, P.; Collier, U.; Pittock, J. Rivers at risk: Dams and the future of freshwater ecosystems. In Proceedings of the 7th International River Symposium; World Wide Fund for Nature (WWF): Gland, Switzerland, September 2004; Volume 4.

2. Kang, H.; Sridhar, V. A near-term drought assessment using hydrological and climate forecasting in the Mekong River Basin. Int. J. Climatol. 2020, 41, joc.6860. [CrossRef]

3. Kang, H.; Sridhar, V.; Mainuddin, M.; Trung, L. Future rice farming threatened by drought in the Lower Mekong Basin. Sci. Rep. 2021, 11, 9383. [CrossRef]

4. Li, Y.; Lu, H.; Yang, K.; Wang, W.; Tang, Q.; Khem, S.; Yang, F.; Huang, Y. Meteorological and hydrological droughts in Mekong River Basin and surrounding areas under climate change. J. Hydrol. Reg. Stud. 2021, 36, 100873. [CrossRef]

5. Ali, S.A.; Sridhar, V. Deriving the Reservoir Conditions for Better Water Resource Management Using Satellite-Based Earth Observations in the Lower Mekong River Basin. Remote Sens. 2019, 11, 2872. [CrossRef]

6. Yun, X.; Tang, Q.; Wang, J.; Liu, X.; Zhang, Y.; Lu, H.; Wang, Y.; Zhang, L.; Chen, D. Impacts of climate change and reservoir operation on streamflow and flood characteristics in the Lancang-Mekong River Basin. J. Hydrol. 2020, 590, 125472. [CrossRef]

7. Ali, S.A.; Sridhar, V. Tradeoffs between irrigation and hydropower in the Lower Mekong River Basin. Clim. Chang. 2021, under review.

8. Zhong, R.; Zhao, T.; Chen, X. Evaluating the tradeoff between hydropower benefit and ecological interest under climate change: How will the water-energy-ecosystem nexus evolve in the upper Mekong basin? Energy 2021, 237, 121518. [CrossRef]

9. Hecht, J.S.; Lacombe, G.; Arias, M.E.; Dang, T.D.; Piman, T. Hydropower dams of the Mekong River basin: A review of their hydrological impacts. J. Hydrol. 2019, 568, 285-300. [CrossRef]

10. Sridhar, V.; Ali, S.A.; Kansal, M.L. A Holistic Approach for Designing Environmental Flows in the Lower Mekong Basin. In Proceedings of the World Environmental and Water Resources Congress 2021: Planning a Resilient Future along America's Freshwaters, Virtual, 7-11 June 2021; pp. 829-839.

11. Thompson, J.R.; Laizé, C.L.R.; Green, A.J.; Acreman, M.C.; Kingston, D.G. Climate change uncertainty in environmental flows for the Mekong River. Hydrol. Sci. J. 2014, 59, 935-954. [CrossRef]

12. Kansal, M.L.; Sridhar, V.; Mwanga, E.E. Transboundary Issues of Water Governance in Mekong River Basin. In Proceedings of the World Environmental and Water Resources Congress, Virtual, 7-11 June 2021; American Society of Civil Engineers: Pittsburgh, PA, USA, 2019; pp. 130-143.

13. Li, D.; Zhao, J.; Govindaraju, R.S. Water benefits sharing under transboundary cooperation in the Lancang-Mekong River Basin. J. Hydrol. 2019, 577, 123989. [CrossRef]

14. Sridhar, V.; Jin, X.; Jaksa, W.T.A. Explaining the hydroclimatic variability and change in the Salmon River basin. Clim. Dyn. 2013, 40, 1921-1937. [CrossRef]

15. Sridhar, V.; Billah, M.M.; Hildreth, J.W. Coupled Surface and Groundwater Hydrological Modeling in a Changing Climate. Groundwater 2018, 56, 618-635. [CrossRef]

16. Sridhar, V.; Kang, H.; Ali, S.A. Human-Induced Alterations to Land Use and Climate and Their Responses for Hydrology and Water Management in the Mekong River Basin. Water 2019, 11, 1307. [CrossRef]

17. Sridhar, V.; Anderson, K.A. Human-induced modifications to land surface fluxes and their implications on water management under past and future climate change conditions. Agric. For. Meteorol. 2017, 234-235, 66-79. [CrossRef]

18. Seong, C.; Sridhar, V.; Billah, M.M. Implications of potential evapotranspiration methods for streamflow estimations under changing climatic conditions. Int. J. Climatol. 2018, 38, 896-914. [CrossRef]

19. Kang, H.; Sridhar, V. Improved Drought Prediction Using Near Real-Time Climate Forecasts and Simulated Hydrologic Conditions. Sustainability 2018, 10, 1799. [CrossRef]

20. Sehgal, V.; Sridhar, V.; Tyagi, A. Stratified drought analysis using a stochastic ensemble of simulated and in-situ soil moisture observations. J. Hydrol. 2017, 545, 226-250. [CrossRef]

21. Conway, D.; Van Garderen, E.A.; Deryng, D.; Dorling, S.; Krueger, T.; Landman, W.; Lankford, B.; Lebek, K.; Osborn, T.; Ringler, C.; et al. Climate and southern Africa's water-energy-food nexus. Nat. Clim. Chang. 2015, 5, 837-846. [CrossRef]

22. Leck, H.; Conway, D.; Bradshaw, M.; Rees, J. Tracing the Water-Energy-Food Nexus: Description, Theory and Practice. Geogr. Compass 2015, 9, 445-460. [CrossRef]

23. Rasul, G.; Sharma, B. The nexus approach to water-energy-food security: An option for adaptation to climate change. Clim. Policy 2016, 16, 682-702. [CrossRef] 
24. Chapman, A.; Darby, S. Evaluating sustainable adaptation strategies for vulnerable mega-deltas using system dynamics modelling: Rice agriculture in the Mekong Delta's an Giang Province, Vietnam. Sci. Total Environ. 2016, 559, 326-338. [CrossRef] [PubMed]

25. Dang, T.D.; Vu, D.T.; Chowdhury, A.F.M.K.; Galelli, S. A software package for the representation and optimization of water reservoir operations in the VIC hydrologic model. Environ. Model. Softw. 2020, 126, 104673. [CrossRef]

26. Feng, M.; Liu, P.; Li, Z.; Zhang, J.; Liu, D.; Xiong, L. Modeling the nexus across water supply, power generation and environment systems using the system dynamics approach: Hehuang Region, China. J. Hydrol. 2016, 543, 344-359. [CrossRef]

27. Pittock, J.; Dumaresq, D.; Bassi, A. Modeling the Hydropower-Food Nexus in Large River Basins: A Mekong Case Study. Water 2016, 8, 425. [CrossRef]

28. Stone, R. Mayhem on the Mekong. Science 2011, 333, 814-818. [CrossRef] [PubMed]

29. Ali, S.A.; Sridhar, V. Evapotranspiration assessment in the context of food, energy, and water nexus in the lower Mekong River basin. In Proceedings of the World Environmental and Water Resources Congress 2019: Watershed Management, Irrigation and Drainage, and Water Resources Planning and Management-Selected Papers from the World Environmental and Water Resources Congress 2019, Pittsburgh, PA, USA, 19-23 May 2019; American Society of Civil Engineers (ASCE): Pittsburgh, PA, USA, 2019; pp. 48-62.

30. Browder, G.; Ortolano, L. The Evolution of an International Water Resources Management Regime in the Mekong. Nat. Resour. J. 2000, 40, 499-531.

31. Plengsaeng, B.; Wehn, U.; van der Zaag, P. Data-sharing bottlenecks in transboundary integrated water resources management: A case study of the Mekong River Commission's procedures for data sharing in the Thai context. Water Int. 2014, 39, 933-951. [CrossRef]

32. Gerlak, A.K.; Lautze, J.; Giordano, M. Water resources data and information exchange in transboundary water treaties. Int. Environ. Agreem. Polit. Law Econ. 2011, 11, 179-199. [CrossRef]

33. Aliagha, C. Environmental Clearinghouse as an Institutional Incentive for Data and Information Sharing and Conflict Reuction in the Mekong River Basin; OpenSIUC; Southern Illinois University: Carbondale, IL, USA, 2004; pp. 7-20.

34. Affeltranger, B. Mekong Studies at Crossed Glances. In Proceedings of the 4th French-MFU Seminar, Chiang Rai, Thailand, February 2009.

35. Affeltranger, B. Sustainability of Environmental Regimes: The Mekong River Commission; Springer: Berlin/Heidelberg, Germany, 2009; pp. 593-601.

36. Thu, H.N.; Wehn, U. Data sharing in international transboundary contexts: The Vietnamese perspective on data sharing in the Lower Mekong Basin. J. Hydrol. 2016, 536, 351-364. [CrossRef]

37. Khandelwal, A.; Karpatne, A.; Wei, Z.; Kuang, H.; Ghosh, R.; Dugan, H.; Hanson, P.; Kumar, V. GLADD-R: A New Global Lake Dynamics Database for Reservoirs Created Using Machine Learning and Satellite Data GLADD-R: A New Global Lake Dynamics Database for Reservoirs; University of Minnesota: Minneapolis, MN, USA, 2019.

38. Liang, X.; Lettenmaier, D.P.; Wood, E.F.; Burges, S.J. A simple hydrologically based model of land surface water and energy fluxes for general circulation models. J. Geophys. Res. 1994, 99, 14415. [CrossRef]

39. Lohmann, D.; Raschke, E.; Nijssen, B.; Lettenmaier, D.P. Regional scale hydrology: II. Application of the VIC-2L model to the Weser River, Germany. Hydrol. Sci. J. 1998, 43, 143-158. [CrossRef]

40. Lohmann, D.; Nolte-Holube, R.; Raschke, E. A large-scale horizontal routing model to be coupled to land surface parametrization schemes. Tellus Ser. A Dyn. Meteorol. Oceanogr. 1996, 48, 708-721. [CrossRef]

41. Haddeland, I.; Lettenmaier, D.P.; Skaugen, T. Effects of irrigation on the water and energy balances of the Colorado and Mekong river basins. J. Hydrol. 2006, 324, 210-223. [CrossRef]

42. Hook, J.; Novak, S.; Johnston, R. Social Atlas of the Lower Mekong Basin; Mekong River Commission: Phnom Penh, Cambodia, 2003; pp. 1727-1800.

43. Sheffield, J.; Goteti, G.; Wood, E.F. Development of a 50-Year High-Resolution Global Dataset of Meteorological Forcings for Land Surface Modeling. J. Clim. 2006, 19, 3088-3111. [CrossRef]

44. Kalnay, E.; Kanamitsu, M.; Kistler, R.; Collins, W.; Deaven, D.; Gandin, L.; Iredell, M.; Saha, S.; White, G.; Woollen, J.; et al. The NCEP/NCAR 40-Year Reanalysis Project. Bull. Am. Meteorol. Soc. 1996, 77, 437-471. [CrossRef]

45. Mitchell, T.D.; Jones, P.D. An improved method of constructing a database of monthly climate observations and associated high-resolution grids. Int. J. Climatol. 2005, 25, 693-712. [CrossRef]

46. Huffman, G.J.; Adler, R.F.; Morrissey, M.M.; Bolvin, D.T.; Curtis, S.; Joyce, R.; McGavock, B.; Susskind, J. Global Precipitation at One-Degree Daily Resolution from Multisatellite Observations. J. Hydrometeorol. 2001, 2, 36-50. [CrossRef]

47. Huffman, G.; Adler, R.; Stocker, E.; Bolvin, D.; Nelkin, E. Analysis of TRMM 3-hourly multi-satellite precipitation estimates computed in both real and post-real time. In Proceedings of the 12th Conference on Satellite Meteorology and Oceanography, Long Beach, CA, USA, 8-13 February 2003; American Meteorological Society: Boston, MA, USA, 2003 ; pp. 4-11.

48. Stackhouse, P.W.; Gupta, S.K.; Cox, S.J.; Mikowitz, J.C.; Zhang, T.; Chiacchio, M. 12-year surface radiation budget data set. GEWEX News 2004, 14, 10-12.

49. Franchini, M.; Pacciani, M. Comparative analysis of several conceptual rainfall-runoff models. J. Hydrol. 1991, 122, 161-219. [CrossRef]

50. Cosby, B.J.; Hornberger, G.M.; Clapp, R.B.; Ginn, T.R. A Statistical Exploration of the Relationships of Soil Moisture Characteristics to the Physical Properties of Soils. Water Resour. Res. 1984, 20, 682-690. [CrossRef] 
51. Wood, E.F.; Lettenmaier, D.P.; Zartarian, V.G. A land-surface hydrology parameterization with subgrid variability for general circulation models. J. Geophys. Res. 1992, 97, 2717. [CrossRef]

52. Bonnema, M.; Hossain, F. Inferring reservoir operating patterns across the Mekong Basin using only space observations. Water Resour. Res. 2017, 53, 3791-3810. [CrossRef]

53. Costa-Cabral, M.C.; Richey, J.E.; Goteti, G.; Lettenmaier, D.P.; Feldkötter, C.; Snidvongs, A. Landscape structure and use, climate, and water movement in the Mekong River basin. Hydrol. Process. 2008, 22, 1731-1746. [CrossRef]

54. Teluguntla, P.; Thenkabail, P.; Xiong, J.; Gumma, M.; Giri, C.; Milesi, C.; Ozdogan, M.; Congalton, R.; Tilton, J.; Sankey, T.; et al. NASA Making Earth System Data Records for Use in Research Environments (MEaSUREs) Global Food Security Support Analysis Data (GFSAD) Crop Mask 2010 Global 1 km V001. Available online: https:/ / pdaac.usgs.gov/products/gfsad1kcmv001/ (accessed on 9 September 2021).

55. Zhou, T.; Nijssen, B.; Gao, H.; Lettenmaier, D.P.; Zhou, T.; Nijssen, B.; Gao, H.; Lettenmaier, D.P. The Contribution of Reservoirs to Global Land Surface Water Storage Variations. J. Hydrometeorol. 2016, 17, 309-325. [CrossRef]

56. Hempel, S.; Frieler, K.; Warszawski, L.; Schewe, J.; Piontek, F. A trend-preserving bias correction-The ISI-MIP approach. Earth Syst. Dyn. 2013, 4, 219-236. [CrossRef]

57. Paper, W. GoldSim: Engineering and Environmental Simulation Software for Water Resource Applications; GoldSim: Seattle, WA, USA, 2009.

58. Liu, X.; Tang, Q.; Voisin, N.; Cui, H. Projected impacts of climate change on hydropower potential in China. Hydrol. Earth Syst. Sci. 2016, 20, 3343-3359. [CrossRef]

59. Box, M.J. A new method of constrained optimization and a comparison with other methods. Comput. J. 1965, 8, 42-52. [CrossRef]

60. Ming, B.; Liu, P.; Chang, J.; Wang, Y.; Huang, Q. Deriving Operating Rules of Pumped Water Storage Using Multiobjective Optimization: Case Study of the Han to Wei Interbasin Water Transfer Project, China. J. Water Resour. Plan. Manag. 2017, 143, 05017012. [CrossRef] 